\title{
EVALUASI KEGIATAN SURVEILANS EPIDEMIOLOGI DI PELABUHAN DALAM UPAYA PENCEGAHAN WABAH FLU BURUNG (STUDI KASUS DI PELABUHAN MALUNDUNG KKP KELAS II TARAKAN)
}

\author{
Jamaludin Abduh Al Ghozali \\ Kantor Kesehatan Pelabuhan Kelas II Tarakan \\ Tarakan, Kalimantan Utara \\ Alamat Korespondensi: \\ Jamaludin Abduh Al Ghozali \\ Email: jamaludin.abduh@gmail.com
}

\begin{abstract}
ABSTRAK
Kasus flu burung masih menjadi perhatian dunia internasional termasuk Indonesia setelah pertama kali ditemukan di China dan meluas hingga ke Indonesia dan menyebabkan 165 orang meninggal dunia hingga tahun 2014. Kasus flu burung pun ditetapkan menjadi Kejadian Luar Biasa (KLB) di Indonesia saat itu. Salah satu instansi yang melakukan tugas pokok dan fungsi surveilans epidemiolog terhadap risiko kejadian wabah flu burung adalah KKP Kelas II Tarakan. Penelitian ini bertujuan melakukan Evaluasi Kegiatan Surveilans Epidemiologi Terhadap Risiko Kejadian Wabah Flu Burung Pada Kapal Asing Di Kantor Kesehataan Pelabuhan Kelas II Tarakan. Rancang bangun penelitian ini adalah penelitian deskriptif dengan pendekatan kualitatif. Variabel Penelitian meliputi input (tenaga, dana, data, metode, sarana), proses (pengumpulan data, pengolahan data, analisis dan interpretasi data) dan output (laporan dan diseminasi laporan). Dari hasil penelitian ada beberapa indikator kecukupan dalam melakukan kegiatan surveilans yang masih kurang dari standar, baik tenaga serta sarana baik transportasi maupun komunikasi. Petugas surveilans yang masih kurang baik dari jumlah hingga kualifikasi, dimana banyak petugas yang merangkap kegiatan lain dan hanya 1 petugas yang pernah mengikuti pelatihan surveilans. Sedangkan dari sarana masih ada yang belum mencukupi yaitu kendaraan, sedangkan untuk kegiatan proses maupun output sudah sesuai indikator yang ditetapkan. Kesimpulan dari penelitian ini adalah kegiatan surveilans epidemiologi di Kantor Kesehatan Pelabuhan Kelas II Tarakan pada proses maupun output sudah berjalan dengan baik dan sesuai dengan indikator, meskipun terjadi kekurangan pada input. Disarankan agar Kantor Kesehatan Pelabuhan Kelas II Tarakan perlu melakukan perekrutan tenaga surveilans, dan pelatihan kepada petugas yang telah ada serta penyediaan sarana transportasi untuk mengantisipasi kekurangan pada input saat kegiatan surveilans.
\end{abstract}

Kata kunci: evaluasi, surveilans epidemiologi, flu burung, pelabuhan

\section{ABSTRACT}

Avian Influenza cases remains an international concern, including Indonesia after it was first discovered in China and spread to Indonesia and caused 165 deaths up to 2014. Avian Influenza cases was set to Extraordinary Events in Indonesia at that time. One of the agencies that perform basic tasks and functions of epidemiological surveillance to the risk of occurrence of Avian Influenza outbreak is Port Health Office Class II Tarakan. This study aims to evaluate epidemiological surveillance operations of Avian Influenza outbreak risk at Foreign Ships in Port Health Office Class II Tarakan. This research was conducted descriptively with qualitative approach. Research variable included input (personnel, funds, data, methods, tools), process (data collection, data processing, analysis and interpretation of data) and output (report and dissemination of the report). From the research there were several indicators of sufficiency in conducting surveillance activities that were still less than the standard, such as personnel, tools, transportation, and communication. Surveillance officers are still less qualified, where many officers who are also tasked with other activities and only one officer who has attended the surveillance training. Vehicle also became one the factor that weren't enough, while the process and 
output indicators has met the standard. The conclusion of this research is that the process and output of epidemiological surveillance activities in the Port Health Office Class II Tarakan has been going well and according to indicators, although there is a shortage on the input. It is recommended that Port Health Office Class II Tarakan need to recruit surveillance officers and give training to officers who have been there as well as the provision of transportation to anticipate input shortages in surveillance activities.

Keywords: evaluation, epidemiological surveillance, avian influenza, port

\section{PENDAHULUAN}

Era globalisasi seperti ini terjadi kemajuan yang sangat pesat terutama di bidang transportasi, yang membuat seseorang dapat melakukan perjalanan lintas benua dari satu negara ke negara lainnya hanya dengan beberapa jam sehingga menyebabkan terjadinya pergeseran epidemiologi penyakit. Hal ini ditandai dengan penularan penyakit dari satu benua ke benua yang lainnya. Globalisasi akan melancarkan perjalanan penyakit antar negara yang dimungkinkan oleh jumlah perpindahan populasi dari suatu negara ke negara lainnya. Sehingga kegiatan pencegahan dan pengawasan sangat perlu dilakukan untuk mengatasi kemungkinan penularan penyakit ke wilayah lain.

Guna mengantisipasi ancaman penyakit global dan kesehatan masyarakat menjadi perhatian dunia internasional, maka dalam International Health Regulations 2005 disebutkan bahwa surveilans epidemiologi merupakan salah satu kemampuan dasar yang harus dimiliki oleh setiap unsur di suatu negara (Depkes RI 2007).

Surveilans epidemiologi adalah kegiatan pengamatan secara sistematis dan terus menerus terhadap penyakit atau masalah-masalah kesehatan serta kondisi yang mempengaruhi risiko terjadinya penyakit atau masalah-masalah kesehatan tersebut agar dapat melakukan tindakan penanggulangan secara efektif dan efisien melalui proses pengumpulan, pengolahan dan analisis serta penyebaran informasi epidemiologi kepada penyelenggara program kesehatan (Depkes RI, 2003).

Salah satu contoh penularan penyakit adalah kasus flu burung. Kasus pertama flu burung ditemukan di China pada tahun 2003.
Wabah flu burung meluas ke beberapa negara dan pada tahun 2005 kasus flu burung terjadi di Indonesia. Mulai tahun 2005 hingga Juni 2014, jumlah kejadian kasus di Indonesia sebanyak 197 kasus flu burung dan 165 diantaranya meninggal dunia (Depkes RI, 2014).

Saat ini di Indonesia banyak faktor yang mempengaruhi terjadinya kasus flu burung, diantaranya kebersihan lingkungan yang sangat kurang. Tidak jarang kita lihat ada beberapa rumah yang sangat berdekatan dengan kandang hewan/unggas yang selama ini merupakan pembawa virus tersebut sehingga manusia yang bersinggungan langsung dengan unggas maupun mengkonsumsi unggas atau turunannya sangat beresiko terkena virus flu burung jika tidak ada antisipasi yang tepat oleh pemerintah maupun masyarakat itu sendiri.

Kasus wabah yang masuk Indonesia bisa dipengaruhi oleh beberapa faktor, diantaranya lemahnya pengawasan terhadap pintu masuk wilayah negara maupun kegiatan surveilans epidemiologi yang belum maksimal, sehingga wabah tersebut bisa menyebar di Indonesia.

Jika ditinjau dari sistem pelayanan kesehatan Indonesia, maka peran dan kedudukan Kantor Kesehatan Pelabuhan (KKP) adalah sebagai ujung tombak sistem surveilans pelayanan kesehatan di Indonesia khususnya di pintu masuk wilayah Indonesia yang meliputi pelabuhan laut, pelabuhan udara dan lintas batas darat negara. Sebagai sarana pelayanan kesehatan terdepan di Indonesia, Kantor Kesehatan Pelabuhan memiliki tugas cegah tangkal dan keluarnya penyakit dari dan ke Indonesia, khususnya penyakit menular potensial wabah yang 
dapat menyebabkan kedaruratan kesehatan masyarakat yang menjadi perhatian dunia (Depkes RI, 2007).

Kantor kesehatan Pelabuhan (KKP) merupakan unit pelaksana teknis di lingkungan Kementerian Kesehatan dan berada di bawah serta bertanggung jawab kepada Direktur Jendral Pengendalian Penyakit dan Penyehatan Lingkungan (Depkes RI, 2008).

KKP Kelas II Tarakan juga memiliki dan menjalankan tugas pokok dan fungsi pencegahan keluar masuknya penyakit. Tugas tersebut dijabarkan dalam fungsi pengawasan terhadap kedatangan kapal asing.

Kedatangan kapal asing yang masuk Indonesia melalui wilayah kerja KKP Kelas II Tarakan pada tahun 2014 sebanyak 3,361 buah dan jumlah ABK asing sebanyak 35,922 orang. Dari jumlah ABK tersebut, sebanyak $50 \%$ berasal dari China yang merupakan daerah endemis flu burung. Selama pengawasan pada tahun 2013, ditemukan sebanyak 8 orang ABK dari China yang memiliki gejala flu burung yaitu demam dan sesak meskipun pemeriksaan lebih lanjut menunjukkan hasil negatif terinfeksi virus flu burung (KKP Tarakan, 2014).

Tujuan dari penelitian ini adalah melakukan evaluasi kegiatan Surveilans epidemiologi di pelabuhan dalam upaya pencegahan wabah flu burung. Dalam penelitian ini adalah (1) Melakukan evaluasi input kegiatan surveilans epidemiologi terhadap kedatangan kapal dari luar negeri di Kantor Kesehatan Pelabuhan Kelas II Tarakan, (2) Melakukan evaluasi proses kegiatan surveilans epidemiologi terhadap kedatangan kapal dari luar negeri di Kantor Kesehatan Pelabuhan Kelas II Tarakan, (3) Melakukan evaluasi output kegiatan surveilans epidemiologi terhadap kedatangan kapal dari luar negeri di Kantor Kesehatan Pelabuhan Kelas II Tarakan.

\section{METODE PENELITIAN}

Jenis penelitian ini termasuk penelitian evaluatif yaitu menilai suatu kegiatan yang telah dilaksanakan dengan membandingkan kriteria atau tujuan yang telah ditetapkan. Rancang bangun penelitian ini adalah penelitian deskriptif yang bertujuan menggambarkan dan menjelaskan secara sistematis fakta-fakta, sifat serta hubungan antar fenomena yang diselidiki (Notoatmodjo, 2012)

Penelitian ini menggunakan pendekatan kualitatif untuk mendapat informasi mendalam dari informan/ sumber data tentang kegiatan yang sudah dilakukan, sehingga penelitian ini mampu menggambarkan keadaan yang sebenarnya di lapangan. Hasil dari penelitian akan dibandingkan dengan teori surveilans epidemiologi.

Obyek penelitian adalah kegiatan surveilans epidemiologi pada kapal asing yang dilakukan oleh Kantor Kesehatan Pelabuhan Kelas II Tarakan. Informan dalam penelitian ini berjumlah 9 orang terdiri dari 1 orang pejabat kepala seksi surveilans epidemiologi dan 3 orang petugas surveilans, 3 orang petugas medis dan 2 orang petugas kesehatan lingkungan di Kantor Kesehatan Pelabuhan Kelas II Tarakan yang terlibat langsung dalam kegiatan surveilans epidemiologi pada kapal asing.

Teknik pengumpulan data kegiatan surveilans diperoleh melalui wawancara mendalam dengan menggunakan instrumen panduan wawancara mendalam dan observasi dokumen untuk melihat pelaksanaan kegiatan surveilans oleh Kantor Kesehatan Pelabuhan Kelas II Tarakan. Data sekunder kegiatan surveilans diperoleh dengan studi dokumen tentang jumlah petugas surveilans epidemiologi serta sarana dan prasarana yang ada di Kantor Kesehatan Pelabuhan Kelas II Tarakan.

Analisis data kegiatan surveilans dilakukan secara deskriptif, yaitu menggambarkan suatu keadaan yang sebenarnya berdasarkan hasil analisis dan interpretasi yang akan digambarkan dalam bentuk tabel, grafik, gambar maupun narasi (Noor, 2008) 


\section{HASIL}

Surveilans epidemiologi di KKP Kelas II Tarakan dilakukan melalui tahapan input, proses, output. Uraian mengenai tahapan tersebut sebagai berikut:

\section{Input \\ Tenaga}

Tenaga surveilans yang ada di Kantor Kesehatan Pelabuhan Kelas II Tarakan terdapat 4 orang yang berada dalam seksie Pengendalian Karantina dan Surevilans Epidemiologi yaitu 1 orang sebagai kepala seksi dengan latar belakang pendidikan S1, 1 orang pengelola program dengan latar belakang S1 dan 2 orang pembatu pengelola program dengan pendidikan D3. Dari hasil wawancara menunjukkan bahwa petugas Pengendalian Karantina dan Surveilans Epidemiologi mendapat tenaga dari seksi Pengendalian Risiko Lingkungan sebanyak 2 orang dan seksi Upaya Kesehatan Lintas Wilayah sebanyak 3 orang, petugas yang ada cukup untuk melaksanakan kegiatan surveilans epidemiologi secara rutin namun jika berdasarkan standar dalam KMK no. 1116 Tahun 2003 tentang penyelenggaraan system surveilans epidemiologi kesehatan tenaga yang ada masih kurang. Petugas yang ada juga yang merangkap sebagai pemegang program lain, terkait dengan adanya rangkap tugas ini membuat beberapa kegiatan surveilans kurang bisa dilaksanakan dengan baik, seperti keterlambatan pelaporan. Sedangkan petugas yang mendapatkan pelatihan epidemiolog hanya 1 orang, sehingga dapat mengganggu kegiatan surveilans jika petugas tidak dapat hadir. Ketersediaan sumber daya petugas yang ada di Kantor Kesehatan Pelabuhan Kelas II Tarakan masih kurang dari standar indikator yang ditentukan, dapat dilihat seperti pada tabel dibawah ini:

\section{Dana}

Dana untuk kegiatan surveilans epidemiologi di wilayah Kantor Kesehatan Pelabuhan Kelas II Tarakan berasal dari anggaran DIPA Kementerian Kesehatan.
Tabel 1. Ketersediaan Sumber Daya

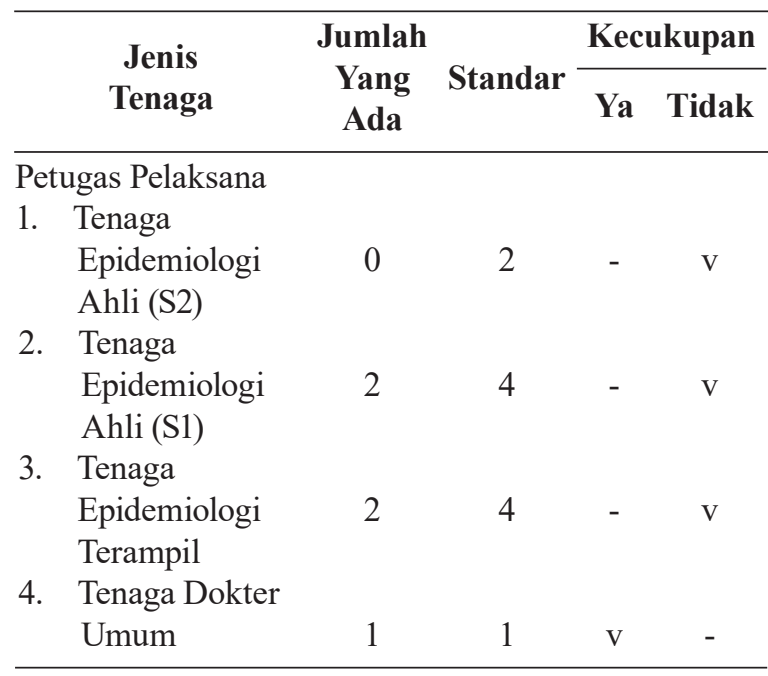

Sumber: KKP Kelas Tarakan, Februari 2016

Dana yang tersedia berdasarkan hasil wawancara sudah cukup untuk melaksanakan kegiatan surveilans epidemiologi pada kapal asing di Kantor Kesehatan Pelabuhan Kelas II Tarakan.

Data

Data adalah merupakan variabel yang penting dalam melakukan kegiatan surveilans epidemiologi, sehingga jenis data yang dikumpulkan oleh petugas surveilans bisa akurat dan valid.

Jenis data dalam melakukan surveilans epidemiologi kapal asing yang dilakukan oleh petugas yaitu data dari asal daerah kedatangan kapal asing, endemis flu burung atau bukan dan data tentang kesehatan ABK kapal asing yang berhubunngan dengan gejala kasus flu burung.

Sumber data kegiatan surveilans epidemiologi kapal asing berasal dari kapten atau ABK kapal asing dan observasi dokumen kesehatan kapal maupun pemeriksaan kesehatan abk kapal asing yang masuk wilayah Indonesia melalui Kantor Kesehatan Kelas II Tarakan, pemeriksaan kesehatan dilakukan oleh petugas medis dari seksi UKLW bersama dengan petugas surveilans.

Frekuensi pengumpulan data pada kegiatan surveilans epidemiologi kapal asing di Kantor Kesehatan Pelabuhan Kelas 
II Tarakan tidak bisa diprediksi karena mengikuti jumlah kedatangan kapal asing yang bisa setiap saat memasuki wilayah Indonesia sehingga frekuensi pengumpulan data tidak dapat di jadwalkan.

Metode

Dalam kegiatan surveilans epidemiologi metode yang ditetapkan sangat penting karena akan menentukan keluaran dari hasil kegiatan surveilans, sehingga bisa mencapai tujuan secara maksimal. Metode yang dilakukan oleh Kantor Kesehatan Pelabuhan Kelas II Tarakan yaitu dengan wawancara kapten kapal dan observasi dokumen dan sanitasi kapal. Metode sudah sesuai dengan prosedur operasional standar yang ditetapkan oleh Dirtjen Pencegahan dan Pengendalian Penyakit Kementerian Kesehatan RI.

\section{Sarana}

Jika dibandingkan dengan indikator sistem penyelenggaraan surveilans epidemiologi masih ada beberapa sarana pendukung yang kurang, padahal saranasarana tersebut sangat diperlukan untuk menunjang kegiatan surveilans epidemiologi sehingga kegiatan tersebut bisa berjalan dengan baik. Salah satunya seperti sarana komunikasi dimana alat komunikasi yang selama ini digunakan masih dengan handphone petugas sendiri. Sehingga apabila kegiatan surveilans epidemiologi dilakukan ditengah lautan maka sangat mengganggu komunikasi antar petugas, dikarenakan sinyal telepon selular di tengah laut tidak sebagus didaratan yang masih sering ada gangguan. Maka diperlukan komunikasi radio atau handy talky tapi jumlah alat komunikasi tersebut masih kurang sesuai dengan indicator yang ada.

Dari hasil wawancara alat transportasi juga masih kurang dari indicator yang ada, sehingga banyak petugas yang menggunakan kendaraan pribadi untuk melakukan tugas surveilans. Ini sangat berpengaruh bagi petugas yang tidak memiliki kendaraan bermotor dan dapat mengganggu kegiatan
Tabel 2. Ketersediaan Sarana

\begin{tabular}{|c|c|}
\hline & Kecukupan \\
\hline
\end{tabular}

\begin{tabular}{lllll}
\hline Sarana & & & & \\
1. Komputer/Laptop & 1 & 1 & $\mathrm{~V}$ & - \\
2. Form Laporan & & & & \\
3. Telpon/ Faximile & 1 & 1 & $\mathrm{~V}$ & - \\
4. Handy talky & 1 & 1 & $\mathrm{~V}$ & - \\
5. Aplikasi & 0 & 3 & - & $\mathrm{V}$ \\
$\quad$ SIMKESPEL & 1 & 1 & $\mathrm{~V}$ & - \\
\hline Transportasi & & & & \\
1. Mobil & 1 & 1 & $\mathrm{~V}$ & - \\
2. Sepeda Motor & 1 & 2 & - & $\mathrm{V}$ \\
\hline
\end{tabular}

Sumber: KKP Kelas Tarakan, Februari 2016

surveilans itu sendiri. Ketersediaan sarana pada kegiatan surveilans juga dapat dilihat pada tabel 2 .

\section{Proses}

Pengumpulan Data

Pengumpulan data yang dilakukan oleh petugas surveilans kepada kapal dilakukan dengan cara pengamatan dan pengawasan secara langsung terhadap kedatangan kapal yang masuk wilayah Indonesia melalui pelabuhan malundung Tarakan.

Pengumpulan data yang dilakukan oleh petugas menggunakan form pemeriksaan yang di isi oleh petugas yang mengawasi berdasarkan wawancara dengan kapten kapal dan observasi dokumen maupun lingkungan. Dari hasil wawancara dapat diketahui bahwa ketepatan dan kelengkapan pengumpulan petugas surveilans KKP Kelas II Tarakan sudah memenuhi standar dari indikator penyelenggaraan surveilans yaitu lebih dari 80\% (Jamaludin, 2016)

Untuk kelengkapan data dari 37 kapal asing yang disurveilans, data yang dikumpulkan oleh petugas surveilans sebanyak 37 form yang menunjukkan bahwa kelengkapan data sebesar 100\%. Sedagkan ketepatan dalam pengumpulan data surveilans kapal asing didapatkan ada 6 laporan yang di kumpulkan lebih dari batas waktu pengumpulan yaitu 24 jam dikarenakan kegiatan surveilans yang 
dilakukan pada hari libur, sehingga ketepatan data menunjukkan hasil $84 \%$ dimana masih cukup baik menurut indikator yang harus diatas $80 \%$. Data dari hasil pengawasan tersebut diserahkan kepada petugas SIMKESPEL untuk dilaporkan maupun dikirimkan atau Dirjen P2P Kementerian Kesehatan (Jamaludin, 2016)

\section{Kompilasi Data}

Data yang masuk akan dilakukan pengecekan terlebih dahulu sebelum di kirim ke Dirjen P2P Kementerian Kesehatan yang meliputi kelengkapan pengisian pelaporan sehingga jika terjadi kesalahan dapat dibetulkan terlebih dahulu. Sedangkan pada kegiatan surveilans kapal asing yang dilakukan oleh petugas dikelompokkan sesuai dengan daerah asal kedatangan kapal tersebut sesuai dengan edaran dari WHO yang diteruskan oleh Kementerian Kesehatan tentang negara-negara terjangkit dari seluruh dunia yang endemis suatu wabah penyakit menular.

\section{Penyajian Data}

Data yang telah diolah berdasarkan faktor risiko dilakukan penyajian data seperti dokumen sertifikat sanitasi kapal serta observasi lingkungan maupun dokumen kesehatan ABK asing (ICV). Data yang tersedia hanya berupa data rekapan yang disajikan dalam bentuk tabel maupun grafik.

Total kapal yang datang dari luar negeri di dominasi oleh daerah tidak terjangkit sebanyak 23 kapal, dan sisanya berasal dari daerah terjangkit

Tabel 3. Jumlah Kedatangan Kapal Asing

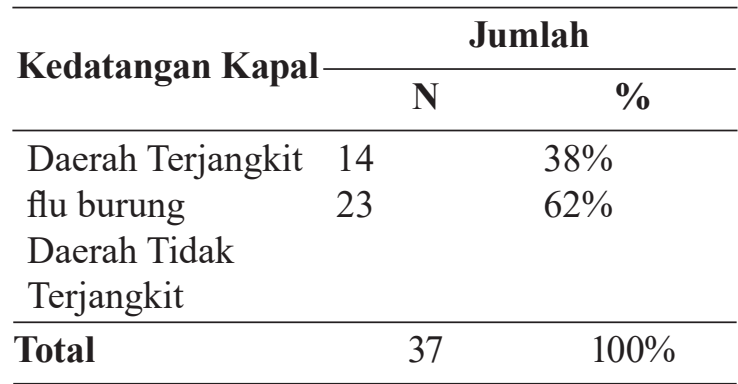

Sumber: KKP Kelas II Tarakan, Februari 2016
Tabel 4. Jumlah ABK Kapal Asing

\begin{tabular}{lcc}
\hline \multirow{2}{*}{ Kedatangan Kapal } & \multicolumn{2}{c}{ Jumlah } \\
\cline { 2 - 3 } & $\mathbf{N}$ & $\mathbf{\%}$ \\
\hline Daerah Terjangkit & 228 & $49 \%$ \\
Daerah Tidak & 234 & $51 \%$ \\
Terjangkit & & \\
\hline Total & 462 & $100 \%$ \\
\hline Sumber: KKP Kelas II Tarakan, 2016 &
\end{tabular}

Berdasarkan tabel diatas kedatangan ABK kapal luar negeri terbanyak dari daerah tidak terjangkit sebanyak $51 \%$, sedangkan kedatangan dari daerah terjangkit sebanyak $49 \%$.

Tabel 5. Kelengkapan Data Vaksin dan ICV

\begin{tabular}{lcc}
\hline \multirow{2}{*}{ Kedatangan Kapal } & \multicolumn{2}{c}{ Jumlah } \\
\cline { 2 - 3 } & Vaksin & ICV \\
\hline Daerah Terjangkit & 228 & $49 \%$ \\
Daerah Tidak & 234 & $51 \%$ \\
Terjangkit & & \\
\hline Total & 462 & $100 \%$ \\
\hline
\end{tabular}

Sumber: KKP Kelas II Tarakan, 2016

Berdasarkan tabel diatas seluruh ABK asing yang datang ke Indonesia melalui Pelabuhan Tarakanbaikdaridaerahterjangkit maupun dari daerah tidak terjangkit telah divaksin dan disertai dengan International Certificate of Vaccination(ICV) yang masih berlaku.

Dari tabel dibawah diketahui bahwa abk asing yang berisiko tinggi tidak ditemukan dengan status sakit saat masuk wilayah Indonesia

Tabel 6. Data Risiko Tinggi dan Kesakitan ABK

\begin{tabular}{lccc}
\hline $\begin{array}{c}\text { Jumlah } \\
\text { ABK }\end{array}$ & $\begin{array}{c}\text { Risiko } \\
\text { Tinggi }\end{array}$ & $\begin{array}{c}\text { Status } \\
\text { Kesakitan }\end{array}$ & $\begin{array}{c}\text { Status } \\
\text { Vaksin }\end{array}$ \\
\hline 462 & 228 & 0 & Lengkap \\
\hline Total & 228 & 0 & \\
\hline
\end{tabular}

Sumber: KKP Kelas II Tarakan, 2016 
Analisis dan Interpretasi Data

Data yang tersedia hanya berupa data rekapan yang disajikan dalam bentuk tabel. Analisis yang dilakukan berupa analisis sederhana dengan membandingkan dengan indikator yang ada. Data yang telah diolah berdasarkan faktor risiko dilakukan analisis deskriptif atas kelengkapan dokumen kesehatan kapal seperti sertifikat sanitasi kapal serta observasi lingkungan maupun dokumen kesehatan ABK asing (ICV) untuk memastikan bahwa kapal dan abk asing yang datang dalam keadaan sehat tanpa membawa penyakit dari negara lain.

\section{Output}

Informasi Epidemiologi

Informasi yang dihasilkan antara lain adalah laporan hasil pengamatan dan pengawasan yang merupakan laporan bulanan, triwulanan, semester dan juga laporan tahunan ke dirjen P2P Kementerian Kesehatan sudah sesuai dengan jumlah laporan yang seharusnya dibuat oleh Kantor Kesehatan Pelabuhan Kelas II Tarakan meliputi data kedatanngan orang asing, surveilans epidemiologi.

\section{Diseminasi Informasi}

Hasil wawancara menunjukkan bahwa telah dilakukan penyebarluasan informasi epidemiologi yang dihasilkan dari sistem surveilans. Diseminasi informasi dilakukan lintas sektoral dengan instansi terkait yang terlibat dalam penegakan hukum diwilayah pelabuhan seperti pelindo, otoritas pelabuhan, rumah sakit juga termasuk bea cukai atau imigrasi. Informasi tersebut disebarluaskan dalam bentuk laporan dan bulletin tahunan.

\section{Masalah yang ditemukan}

Pada pelaksanaan kegiatan surveilans epidemiologi kapal asing di Kantor Kesehatan Pelabuhan Kelas II Tarakan pada bulan Februari 2016 ditemukan beberapa kelemahan diantaranya yaitu, kurangnya tenaga pelaksana kegiatan surveilans yang terlatih atau seorang epidiomolog sehingga beban kerja melebihi kapasitas tenaga yang dimiliki oleh KKP Kelas II Tarakan. Kurangnya sarana alat komunikasi berupa handy talky sehingga komunikasi dilakukan dengan hand phone. Sulitnya melakukan komunikasi dengan ABK kapal asing yang berbeda dalam bahasa dan tidak semua ABK bisa menggunakan bahasa Inggris.

\section{PEMBAHASAN \\ Input}

Tenaga

Petugas surveilans epidemiologi di Kantor Kesehatan Pelabuhan Kelas II Tarakan sudah tersedia, namun jumlah petugas yang ada masih belum mencukupi dan masih banyak petugas yang merangkap tugas dengan kegiatan lainnya sehingga dapat menyebabkan kinerja kegiatan surveilans khususnya pada kapal asing menjadi kurang maksimal. Sedangkan masih banyak petugas surveilans yang belum mendapatkan pelatihan khusus surveilans meskipun masa tugas petugas sudah lama. Padahal pelatihan merupakan komponen kegiatan manajemen surveilans yang penting karena untuk menunjang pelaksanaan surveilans (Murti, 2003). Petugas surveilans yang terlatih maka data yang dihasilkan pun akan lebih baik sehingga informasi epidemiologi yang dihasilkan dapat menggambarkan keadaan sebenaarnya. Pada akhirnya keputusan untuk tindakan pencegahan ataupun penanganannya akan tepat.

Tujuan pelatihan adalah untuk memastikan bahwa seluruh tenaga memiliki dan mampu mempertahankan kompetensi yang dibutuhkan dalam pekerjaan mereka (Winterton, 2007). Sehingga meskipun tenaga surveilans yang ada telah memiliki kompetensi yang dibutuhkan namun kompetensi tersebut masih perlu dijaga. Oleh karena itu pelatihan dibutuhkan untuk memelihara dan meningkatkan kemampuan tenaga petugas surveilans di Kantor Kesehatan Pelabuhan Kelas II Tarakan. Metode pelatihan yang baik dilakukan adalah off the job training yaitu pelatihan 
yang dilakukan diluar situasi kerja yang dilaksanakan jika banyak pekerja yang harus dilatih dan banyak tujuan pelatihan (Rachmawati, 2008). Dilaksanakannya off the job training maka ada kesempatan bertukar pengalaman dengan tenaga lain dari luar institusi dan mendapat ide serta ilmu baru yang dapat diaplikasiakan ditempat kerja. Padahal menurut Sukarna, dkk (2006), tenaga merupakan hal yang esensial dalam suatu organisasi dimana tidak hanya kualitas saja yang baik, namun kuantitas tenaga juga harus baik untuk mendukung tujuan suatu organisasi.

Dana

Sedangkan dana yang tersedia telah mencukupi untuk melakuakan kegiatan surveilans epidemiologi. Dan dana yang tersedia dalam kegiatan surveians epidemiologi di Kantor Kesehatan Pelabuhan Kelas II Tarakan melalui anggaran DIPA Kementerian Kesehatan. Menurut Sukarna, dkk (2006), dalam mendukung suksesnya pembangunan kesehatan, tersedianya alokasi dana yang memadai sangatlah penting.

\section{Data}

Sumber data surveilans epidemiologi kapal asing adalah dari wawancara kapten kapal dan observasi yang dilakukan oleh petugas surveilans. Sehingga kemauan sumber data dalam memberikan data yang valid sangat dipengaruhi oleh motivasi dan kesadaran meskipun tetap akan dilakukan observasi langsung baik dokumen maupun lingkungan. Motivasi sendiri merupakan dorongan atau daya penggerak agar pekerja mau bekerja keras dan memberikan semua kemampuan dan keterampilannya untuk mencapai tujuan tertentu (Mendari, 2010). Sehingga penilaian kinerja petugas surveilans yang baik dalam melakukan tugasnya sangat membantu kegiatan surveilans dalam mencari sumber data yang valid dan akurat. Karena penilaian yang adil dapat meningkatkan motivasi pekerja untuk memperbaiki kinerja (Hariandja, 2002).
Frekuensi pengumpulan data untuk kegiatan surveilans tidak ada jadwal yang ditentukan. Dikarenakan kegiatan surveilans kapal asing itu sendiri tidak dapat dipastikan kegiatannya yang bisa setiap saat datang baik pagi maupun malam, sehingga frekuensi pengumpulan data tersebut juga tidak bisa ditentukan. Dari hasil wawancara dengan petugas input data diketahui bahwa frekuensi pengumpulan data dilakukan maksimal 24jam setelah kegiatan surveilans selesei dilaksanakan.

\section{Metode}

Metode yang dilakukan dalam melaksanakan kegiatan surveilans telah sesuai dengan standar operasional prosedur yang ditentukan oleh Kantor Kesehatan Pelabuhan Kelas II Tarakan mulai dari pelaporan kapal asing masuk yang dilakukan oleh agen kapal, pengisian form pemeriksaan oleh petugas KKP, hingga penerbitan sertifikat free pratique yang merupakan akhir dari kegiatan pemeriksaan surveilans kapal asing. Kapal yang sudah mendapatkan sertifikat tersebut telah selesei dilakukan kegiatan surveilans dan dinyatakan bebas sehingga boleh melakukan aktifitas di wilayah Indonesia.

\section{Sarana}

Sarana yang ada dalam kegiatan sebagian besar sudah mencukupi untuk pelaksanaan surveilans, tetapi ada beberapa sarana kegiatan yang masih kurang untuk menunjang pelaksanaan kegiatan, seperti sarana transportasi dan sarana komunikasi petugas surveilans. Untuk alat komunikasi misalnya, petugas masih menggunakan handphone pribadi yang dimiliki petugas dikarenakan harus menggunakan pulsa pribadi untuk melakukan komunikasi dengan petugas lainnya penggunaan handphone juga sering bermasalah dikarenakan lokasi kegiatan surveilans kapal asing yang berada di tengah laut sehingga sering mengganggu sinyal telepon disaat akan gunakan untuk berkoordinasi dengan petugas lain di 
daratan. Sedangkan sarana komunikasi yang disarankan adalah dengan menggunakan radio atau yang disebut handytalky sehingga komunikasi tetap bisa terus dilakukan tanpa terpengaruh dengan keadaan sinyal meski dalam keadaan cuaca yang buruk sekalipun. Begitupun ketersediaan kendaraan bermotor dalam melaksanakan kegiatan surveilans masih terbatas, sehingga beberapa petugas surveilans harus menggunakan kendaraan pribadi dalam melaksanakan tugas.

Namun kesediaan sarana juga tidak bisa terlepas dengan ketersediaan dana yang diperlukan dalam melaksanakan kegiatan tersebut. Karena penyediaan sarana yang dibutuhkan ini dipengaruhi oleh ketersediaan dana dan kemampuan menyusun anggaran, jika dana dapat disusun dengan baik maka tidak menutup kemungkinan untuk menyediakan sarana yang dibutuhkan. Salah satu hal yang menjadi faktor pendukung dalam keberhasilan program kesehatan adalah kemampuan untuk menyusun anggaran (Supriyanto \& Damayanti, 2007).

\section{Proses}

Pengumpulan Data

Pengumpulan data atau pelaporan dari petugas surveilans dengan menyerahkan form yang di isi oleh petugas dari hasil wawancara dan observasi dokumen kesehatan kapal maupun ABK kapal asing. Pengumpulan data oleh petugas ternyata masih banyak kendala dalam melakukannya, terutama kendala bahasa baik dari kapten kapal dan abk kapal yang diwawancarai maupun petugas surveilans yang masih lemah dalam penggunaan bahasa internasional seperti bahasa inggris. Begitu juga dengan pengetahuan petugas tentang surveilans, dikarenakan ketidak lengkapan dalam pengumpulan data masih ada dalam proses surveilans, hal ini bisa disebabkan oleh pengetahuan petugas atau kesadaran dalam melaksanakan tugas tersebut.

Menurut Maryun (2007) pengetahuan merupakan faktor penting dalam terbentuknya tindakan seseorang sehingga jika pengetahuaanya baik maka kinerja seseorang akan baik juga. Dalam hal pengumpulan data, jika pengetahuan petugas masih kurang, baik itu tentang penguasaan bahasa asingnya, karena yang mereka hadapi hampir keseluruhannya WNA sehingga pemahaman bahasa mutlak dikuasai oleh petugas lapangan untuk memudahkan melakukan pengawasan dan pengamatan dalam kegiatan surveilans tersebut.

\section{Kompilasi Data}

Pengelompokan data dilakukan sesuai dengan tujuan dari sistem surveilans itu sendiri dan karakteristik dari masalah kesehatan yang diamati. Data surveilans yang didapat dikelompokkan berdasarkan dari daerah asal kedatangan kapal asing tersebut, yaitu berasal dari daerah terjangkit atau tidak sesuai dengan edaran tentang daerah endemis yang dikeluarkan oleh WHO.

Karena distribusi menurut tempat juga penting dilakukan untuk mengetahui besar dan jenis masalah kesehatan pada suatu daerah, hal yang perlu dilakukan untuk mengatasi kesehatan disuatu daerah dan keterangan tentang faktor penyebab timbulnya masalah kesehatan dengan membandingkan keadaan geografis dan keadaan penduduk (Hidajah dan Hargono, 2007).

\section{Analisis dan Interpretasi Data}

Data yang ada di kantor kesehatan pelabuhan kelas II Tarakan di analisis secara sederhana yang berupa rekapan dan tabel sederhana. Petugas juga melakukan analisis data tiap bulan, triwulan, semester dan tahunan. Namun analisis dan interpretasi harus dilakukan oleh petugas yang memiliki kemampuan tersebut. Tentu ini juga harus dipelajari dengan pelatihan.

Inti dari sistem surveilans adalah analisis secara sistematis dan terus menerus sehingga data yang dikumpulkan bermanfaat sebab menghasilkan informasi yang akurat dan berkualitas untuk pengambilan keputusan dalam upaya pencegahan dan pengendalian penyakit (Murti, 2003). 
Mengingat pentingnya analisis dalam sistem surveilans maka analisis harus dilakukan dan pelatihan kepada petugas yang melakukan analisis harus dilakukan sehingga informasi yang dihasilkan oleh sistem surveilans akurat dan berkualitas.

\section{Output}

Informasi epidemiologi yang dihasilkan oleh sistem surveilans berupa laporan hasil pengamatan dan pengawasan di kantor kesehatan pelabuhan kelas II Tarakan yang dilaporkan kepada atasan atau Dirjen P2P Kementerian Kesehatan RI. Laporan dalam bentuk aplikasi SIMKESPEL yang telah disediakan oleh Kementerian Kesehatan yang dikirim melalui email dan akan ada feedback dari pusat apabila ada kekurangan maupun masalah dalam pengiriman laporan tersebut. Selain laporan secara vertikal kepada atasan hasil surveilans diseminasi informasi juga dilakukan secara harisontal untuk instansi lintas sektoral sehingga hasil data dari kegiatan surveilans terbut dapat dimanfaatkan oleh program sektor atau instansi lainnya.

Diseminasi informasi bisa dilakukan dalam bentuk bulletin, surat edaran, laporan berkala, forum pertemuan dan publikasi ilmiah (Kemenkes RI, 2014). Upaya untuk lebih memudahkan proses diseminasi dapat dilakukan dengan memanfaatkan sarana teknologi informasi yang mudah diakses. Diseminasi juga dapat dilakukan pada kegiatan monitoring dan evaluasi dengan menyampaikan hasil analisis.

\section{Alternatif pemecahan masalah}

Alternatif pemecahan masalah dari masalah yang ditemukan adalah (1) Menambah jumlah tenaga khususnya tenaga surveilans yang berbasis pendidikan epidemiolog dan mengikuti pelatihan surveilans dengan usulan ke Dirjen P2P Kementerian Kesehatan RI, (2) Usulan pengadaan sarana komunikasi handy talky melalui Kementerian Kesehatan RI, (3) Pembagian waktu kerja dalam kegiatan pengawasan kedatangan kapal asing selama 24 jam (4) Diadakannya pendidikan kursus bahasa asing untuk semua petugas surveilans terutama untuk yang bertugas di lapangan.

\section{SIMPULAN}

Ada beberapa kelemahan dan hambatan dalam kegiatan surveilans epidemiologi kesehatan. Hambatan dan kelemahan ditemukan dari variabel tenaga maupun sarana pendukung yang masih kurang dari indikator yang ditetapkan oleh Kementerian Kesehatan RI. Tenaga yang tersedia masih kurang baik dari segi jumlah maupun kualifikasi yang tersedia. Itu terlihat dari sedikitnya petugas yang telah mendapatkan pelatihan surveilans, dari segi kemampuan bahasa masih banyak petugas yang kurang menguasai bahasa Inggris dimana bahasa tersebut merupakan alat komunikasi yang vital dengan kapten maupun ABK yang berasal dari luar wilayah Indonesia.

Karena sarana penunjang sangat penting untuk mendapatkan hasil maksimal pada saat dilaksanakan kegiatan surveilans. Seperti kurangnya alat komunikasi seperti handytalky yang bisa menunjang kegiatan surveilans di segala cuaca terlebih kegiatan surveilans epidemiologi yang dilakukan oleh Kantor Kesehatan Pelabuhan Kelas II Tarakan lebih banyak di tengah laut yang minim sinyal telepon seluler. Begitu juga dengan kendaraan dinas yang masih kurang mencukupi sehingga petugas harus menggunakan kendaraan pribadi.

Kegiatan proses pada surveilans sudah mencukupi dari indikator yang ditetapkan oleh Kementerian Kesehatan RI, dimana kegiatan pengumpulan data mulai kelengkapan dan ketepatan data sudah melebihi $80 \%$.

Output atau keluaran hasil surveilans yang dilakukan oleh Kantor Kesehatan Pelabuhan Kelas II Tarakan baik secara vertikal maupun horizontal sudah cukup baik. Pelaporan telah dilakukan secara rutin ke Ditjen P2P dan tidak pernah terjadi keterlambatan. 
Disarankan agar Kantor Kesehatan Pelabuhan Kelas II Tarakan perlu melakukan perekrutan tenaga surveilans, dan pelatihan kepada petugas yang telah ada serta penyediaan sarana transportasi untuk mengantisipasi kekurangan pada input saat kegiatan surveilans.

\section{DAFTAR PUSTAKA}

Depkes, RI. 2003. KEPMENKES 1116/ MENKES/SK/VIII/2003 Tentang Pedoman Penyelenggaraan Sistem Surveilans Epidemiologi Kesehatan, Jakarta.

Depkes RI. 2007. KEPMENKES 424/ MENKES/SK/IV/2007 Tentang Pedoman Upaya Kesehatan Pelabuhan Dalam Rangka Karantina Kesehatan, Jakarta.

Depkes RI. 2008. PERMENKES 356/ MENKES/PER/IV/2008 Tentang Organisasi dan Tata Kerja Kantor Kesehatan Pelabuhan, Jakarta.

Hariandja, Marihot Tua Efendi, 2002. Manajemen Sumber Daya Manusia, Pengadaan, Pengembangan, Pengkompensasian dan Peningkatan Produktifitas Pegawai. Jakarta : PT. Grasindo.

Hidajah, A \& Hargono, A. 2007. Surveilans Epidemiologi Edisi Revisi. Surabaya; Universitas Airlangga.

Jamaludin, A. 2016. Evaluasi Kegiatan Surveilans Epidemiologi Terhadap Risiko Kejadian Wabah Flu Burung Pada Kapal Asing di Pelabuhan Malundung Kantor Kesehatan Pelabuhan Kelas II Tarakan. Skripsi. Surabaya. Universitas Airlangga.

Kemenkes, RI. 2014. PERMENKES 45/MENKES/SK/2014 Tentang Penyelenggaraan Surveilans Kesehatan. Jakarta.
KKP Kelas II Tarakan. 2013. Standart Operasional Prosedur Kegiatan Surveilans Epidemiologi Kapal Asing. KKP Kelas II Tarakan, Tarakan.

KKP Kelas II Tarakan, 2014, Laporan Pemeriksaan Seksie Pengendalian Karantina dan Surveilans Epidemiologi. KKP Kelas II Tarakan, Tarakan

Maryun, Yayun, 2007. Beberapa Faktor Yang Berhubungan dengan Kinerja Petugas Program TB Paru Terhadap Cakupan Penemuan Kasus Baru BTA di Kota Tasikmalaya Tahun 2006. Tesis. Semarang. Universitas Diponegoro.

Mendari, Anastasia Sri. 2010. Aplikasi Teori Hirarki Kebutuhan Maslow dalam Meningkatkan Motivasi Belajar Mahasiswa. Widya Warta No.1 Tahun XXXIV; 82-92.

Murti, Bhisma. 2003, Prinsip dan Metode Riset Epidemiologi. Yogyakarta: Gadjah Mada Univ. Press.

Notoatmodjo, S, 2012, Metodelogi Penelitian Kesehatan, Jakarta: Rineka Cipta.

Noor, N.N, 2008 Epidemiologi, Jakarta: Rineka Cipta.

Rachmawati, Ike Kusdyah, 2008. Manajemen Sumber Daya Manusia. Yogyakarta; Andi Offset.

Sukarna, Laode, A., Nanis, B., Sigit, R. 2006. Analisis Kesiapan Dinas Kesehatan dalam Mengalokasikan Anggaran Kesehatan pada Era Desentralisasi. Jurnal Management Pelayanan Kesehatan. 9(1); 10-18.

Supriyanto, Stefanus \& N.ADamayanti. 2007. Perencanaan dan Evaluasi. Surabaya; Airlangga University Press.

Winterton, Jonathan. 2007. Oxford Handbook of Human Resource Management Training, Development, and Competence. Oxford University Press. 